\title{
THE FALL AND RISE OF THE EXIT CONSENT
}

\author{
KEEGAN S. DRAKE†
}

\begin{abstract}
Bond issuers wanting to restructure their distressed debt often propose an exchange offer, in which the issuer persuades its bondholders to swap their present holdings for new bonds capable of being honored. To guard against nonparticipating bondholders, issuers may pair their exchange offers with an exit consent. A use of a bond's modification clause, an exit consent is a technique by which bondholders participating in the exchange also vote to impair the distressed bonds.

Use of the exit consent raises a contract question about the duty of good faith and fair dealing. For a quarter of a century, exit consents survived judicial scrutiny when they followed the Delaware case Katz $\mathrm{v}$. Oak Industries Inc. Then, in a case emblematic of the recent Eurozone economic crisis, Assénagon Asset Management v. Irish Bank Resolution Corp., an English court found that the exit consent breached this doctrinal duty, seemingly upending Katz's position as the seminal case on exit consents. This Note argues that such concern is misplaced, concluding that Assénagon augments but does not replace Katz. It proposes reconciling the two cases in a manner that upholds the common values of each case in an effort to provide stable legal principles amid markets in flux.
\end{abstract}

Copyright (C) 2014 Keegan S. Drake.

$\dagger$ Duke University School of Law, J.D. expected 2014; Duke University Fuqua School of Business, M.B.A. expected 2014; University of Oklahoma, B.A. 2004. A generous Fuller-Purdue Grant funded my research. Thanks go to Mitu Gulati, who introduced me to law and finance; to Paige Gentry and Andrew Jennings, who commented on an early draft; to Jeremy Mullem, who helped me refine ideas into prose; and to the editors of (and, now, my friends on) the Duke Law Journal, whose expertise shaped that prose into this Note. The greatest thanks go to my family, who patiently endured my search for a real job. 
If you have a 50 Dollar debt, you're called a scrounger.... Having a 50 million Dollar debt means you're a financial genius. And only a government can have a 50 billion Dollar debt.

- Anonymous ${ }^{1}$

\section{INTRODUCTION}

The year 2008 infamously saw many insolvent ${ }^{2}$ household $^{3}$ and corporate $^{4}$ borrowers. Yet even in the year of "fundamental... changes in business paradigms and the spectacular self-destruction of storied institutions," 5 few insolvencies threatened as many paradigms - or were nearly as spectacular-as that of Anglo Irish Bank (Anglo Irish). Barely one year after posting record profits of $€ 1.2$ billion, ${ }^{6}$ Anglo Irish disclosed heavy losses from investments in commercial real estate, subprime residential mortgages, and collapsed American and Icelandic banks. ${ }^{7}$ Because of Anglo Irish's importance to the Irish economy, ${ }^{8}$ the bank's financial tailspin "hurried the government into action," first, to guarantee the bank's most precarious bonds, ${ }^{10}$ and, eventually, to bail out and nationalize the

1. Jochen Felsenheimer, How To Be a Zillionaire*, CREDIT NEWSL. (Assénagon Credit Mgmt GmbH, Munich, Ger.), Sept. 22, 2010, at 1, available at http://www.assenagon.com/ uploads/media/Credit_Newsletter_2010_07_en_01.pdf. Dr. Jochen Felsenheimer, of Assénagon Asset Management S.A., added that, because of "recent developments, all of the above figures should be multiplied by 100 to reflect reality more accurate[ly]." Id.

2. Insolvency is the inability "to pay one's debts as they fall due or in the usual course of business." BLACK'S LAW DICTIONARY 867 (9th ed. 2009). Insolvency is distinct from bankruptcy, which is the statutory process by which a debtor, who is usually insolvent, seeks financial relief via a judicially supervised process for satisfying his creditors. See id. at 166-67.

3. Ian Bremmer \& Nouriel Roubini, Expect the World Economy To Suffer Through 2009, WALL ST. J., Jan. 23, 2009, at A15 (describing the chain of consequences flowing from U.S. monetary policy, eventually resulting in "insolvent households").

4. Noam Cohen, A Word Insolvent Companies Avoid, N.Y. TIMES, Dec. 22, 2008, at B6 (listing a variety of corporate insolvencies declared in 2008).

5. Andrew Ross Sorkin, Too Big To FaIl: The Inside Story of How Wall Street and Washington Fought To SAVE the FinANCIAL System From CRISIS-AND THEMSELVES 7 (2009).

6. Laura Slattery, Planet Business, IRISH TIMES, Nov. 30, 2007, at 4.

7. In Brief, WALL ST. J., Dec. 4, 2008, at C2.

8. Michael Lewis describes Anglo Irish as one of three banks in Ireland taking on so much debt that their losses "would absorb every penny of Irish taxes for at least the next three years." Michael Lewis, When Irish Eyes Are Crying, VANITY FAIR, Mar. 2011, at 174, 176.

9. Simon Carswell, More Questions than Answers on Government Recapitalisation Proposal, IRISH TIMES, Dec. 16, 2008, at 20.

10. Id. 
bank. ${ }^{11}$ Then, with the threat of systemic risk ${ }^{12}$ seemingly contained, the government announced its plan for "appropriate burdensharing." 13

Burden sharing essentially meant the Irish government would lower its cost to operate Anglo Irish by persuading the fallen bank's bondholders to accept lower bond payments. Such restructurings occur through an exchange offer, in which a bond issuer encourages its bondholders to swap the bonds nearing default for new bonds that the issuer can honor. ${ }^{14}$ A complication arises when some bondholders refuse to participate or hold out for a more favorable alternative. ${ }^{15}$ Because the distressed ${ }^{16}$ bonds continue to be valid contracts until surrendered, ${ }^{17}$ holdouts can sue for full payment, upending an issuer's prime motivation for an exchange. ${ }^{18}$ Thus, as a preventative measure against holdouts, many insolvent institutional debtors do as Anglo Irish did and pair their exchange offers with exit consents. A use of a bond's modification clause, ${ }^{19}$ an exit consent provides that the bondholders agreeing to an exchange for new bonds, as a term of their acceptance, pledge their votes to impair the contract language of the old bonds. ${ }^{20}$ The goal is to make the old bonds comparably

11. Arthur Beesley, Where Does the State Go from Here?, IRISH TIMES, Jan. 21, 2009, at 18.

12. See Steven L. Schwarcz, Systemic Risk, 97 GEO. L.J. 193, 198-99 (2008) ("A common factor in the various definitions of systemic risk is that a trigger event, such as an ... institutional failure, causes a chain of bad economic consequences ....").

13. Press Release, Minister for Finance, Minister's Statement on Banking (Sept. 30, 2010), available at http://www.finance.gov.ie/news-centre/press-releases/minister's-statement-banking30-september-2010.

14. John C. Coffee, Jr. \& William A. Klein, Bondholder Coercion: The Problem of Constrained Choice in Debt Tender Offers and Recapitalizations, 58 U. CHI. L. REV. 1207, 122425 (1991).

15. Steven L. Schwarcz, Global Decentralization and the Subnational Debt Problem, 51 DUKE L.J. 1179, 1250 (2002).

16. See William W. Bratton, Corporate Finance: CASES AND Materials 341 (6th ed. 2008) (describing "distress" generally as a situation in which a corporate debtor is "in financial difficulty" and therefore requires a "lessening [of] its debt obligations").

17. See 1 Arthur Linton Corbin, Corbin on Contracts $\S 1.4$, at 14 (Joseph M. Perillo ed., rev. ed. 1993) (terming a trust indenture, the contractual language that backs a bond, a "contract of adhesion"); AARON RACHELSON, CORPORATE ACQUISITIONS, MERGERS, AND DivESTITURES $\S 11: 134$ (2013), available at CAMD $\S 11: 134$ (Westlaw) ("The legal treatment of debtholders-what is referred to as the 'bond doctrine'-focuses on the proposition that the rights of debtholders are limited to the terms of their contract.").

18. Marcel Kahan, Rethinking Corporate Bonds: The Trade-Off Between Individual and Collective Rights, 77 N.Y.U. L. REV. 1040, 1055-56 (2002).

19. See infra Part I.B.

20. Coffee \& Klein, supra note 14 , at 1224-25. 
unattractive and thereby incent would-be holdouts to participate in the exchange, or at least to render their recalcitrance toothless. ${ }^{21}$

Bondholders may challenge exit consents as a breach of the implied contractual duty of good faith and fair dealing. ${ }^{22}$ Under the leading case on exit consents, Katz v. Oak Industries Inc., ${ }^{23}$ an issuer meets this duty as long as its behavior is not "wrongfully coercive." ${ }^{24}$ To make this determination, Katz instructs courts to consider whether the original contracting parties would have permitted the exit consent's terms had they foreseen them at the time of contracting. ${ }^{25}$ In the quarter century that followed, exit consents were deemed permissible when they complied with the requirements of $\mathrm{Katz}$. When one of Anglo Irish's holdout investors sued in a case arising from the burden-sharing program, however, an English court refused to follow Katz. In Assénagon Asset Management v. Irish Bank Resolution Corp. ${ }^{26}$ the Chancery Division of the High Court of Justice in England called exit consents an abuse of "the purposes for which [bondholder] majorities ... are given power to bind minorities, ${ }^{27}$ and found a breach of the good faith duty laterally as among the bondholders. ${ }^{28}$ The Court of Appeal was scheduled to hear arguments appealing the lower court's ruling, but, at the eleventh hour, Irish Bank Resolution Corp. (IBRC) dropped its appeal, leaving the High Court's ruling to stand. ${ }^{29}$

One scholar encapsulated the legal community's collective reaction to Assénagon when she asked whether England had "killed" the exit consent. ${ }^{30}$ Neither hyperbolic nor hypothetical, her question evoked twin sources of uncertainty. In the short term, this uncertainty has flowed from the starkly different legal treatment exit consents have received on the other side of the Atlantic. Bond contracts

21. $I d$.

22. RESTATEMENT (SECOND) OF CONTRACTS § 205 (1981).

23. Katz v. Oak Indus. Inc., 508 A.2d 873 (Del. Ch. 1986).

24. Id. at 880; see infra Part II.B.1.

25. Katz, 508 A.2d at 879-80; see infra Part II.B.1.

26. Assénagon Asset Mgmt. S.A. v. Irish Bank Resolution Corp., [2012] EWHC (Ch) 2090 (Eng.).

27. Id. [85].

28. See id. (describing the abuse of power as occurring when an individual bondholder votes to the detriment of other bondholders in the same class).

29. Sandrine Bradley, Creditors Circle IBRC over $€ 1.8 b n$ Loss, INT'L FinANCING REV., (Mar. 15, 2013), http://www.ifre.com/creditors-circle-ibrc-over-€18-bn-loss/21074204.article.

30. Anna Gelpern, Exit Consents Killed in England?, CREDIT SuIPS (July 27, 2012, 2:22 PM), http://www.creditslips.org/creditslips/2012/07/exit-consents-killed-in-england.html. 
predominantly contain English or New York choice-of-law provisions ${ }^{31}$ suggesting that otherwise identical bonds could receive disparate treatment because of their choice-of-law clauses. ${ }^{32}$ In the long term, this uncertainty has flowed from what Assénagon might mean on this side of the Atlantic. As a Delaware case, Katz has merely persuasive authority under New York law. ${ }^{33}$ To the extent that Assénagon was more persuasive ${ }^{34}$ and English law remains ascendant in the realm of finance,,$^{35}$ the question then arises whether this apparent transatlantic split might actually presage a new unanimity in which Assénagon becomes the seminal case on exit consents.

Ever in the background of this legal debate are global economic events. Indeed, there continue to be many insolvent borrowers, an important subset of which-sovereign borrowers-lack the ability to declare bankruptcy and therefore have no effective means of restructuring outside of exchange offers. ${ }^{36}$ While the Eurozone sovereign-debt crisis persists as a macroeconomic albatross ${ }^{37}$ any

31. Many also contain German choice-of-law provisions, but German bonds require a unanimous vote of bondholders for modification and thus are not susceptible to exit consents. See InT'L MONETARY Fund, REVIEWING THE PROCESS FOR SOVEREIGN DebT REstructuring Within THE Existing LEGAL FrAMEWORK 25, 29 (2003), available at https:/www.imf.org/external/np/pdr/sdrm/2003/080103.pdf.

32. See Gelpern, supra note 30 ("Tons of past and imminent restructurings (think Spanish banks) are at stake.").

33. When courts in New York have cited Katz, they have done so to support the general proposition that borrower-lender relationships are contractual in nature. See, e.g., United States v. Jolly, 102 F.3d 46, 48 (2d Cir. 1996) ("[A] firm's obligations to creditors are generally regarded solely as contractual.”); Page Mill Asset Mgmt. v. Credit Suisse First Bos. Corp., No. 98 CIV. 6907 MBM, 2000 WL 335557, at *11 (S.D.N.Y. Mar. 30, 2000) (using Katz to support bond duties being contractual, rather than fiduciary, in nature).

34. 1 CARMODY-WAit 2d: NEW YORK PRACTICE WITH FORMS $§ 2: 336$ (2007), available at CW2D $§ 2: 336$ (Westlaw) (citations omitted) (noting that, because the common law of New York derives from the common law of England, English court decisions have value in New York courts).

35. See Dominic Carman, The Long Arm of the Law-City Firms with a Global Reach, TiMES (London), July 25, 2006, at 4 ("Americans may now export the English language to the world, but English commercial law . . remains a world beater."); Didier Martin \& Forrest G. Alogna, New Delaware, WALl ST. J. (Dec. 20, 2007, 12:01 AM), http://online.wsj.com/news/ articles/SB119810493339240635 (stating that "expensive and restrictive" American regulation makes English law preferable for corporate transactions).

36. Bankruptcy is not an option for sovereign borrowers, as there is no bankruptcy scheme for them. See CARmen M. Reinhart \& Kenneth S. Rogoff, This Time Is Different: EIGHT CENTURIES OF FINANCIAL FOLLY 53 (2009) ("[P]erhaps the most fundamental 'imperfection' of international capital markets [is] the lack of a supernational legal framework for enforcing debt contracts across borders.").

37. Charles Forelle \& Marcus Walker, Euro-Zone Risks Return to Fore, WaLL ST. J., June 14, 2013, at C1; Eduardo Porter, Economists Agree: Solutions Are Elusive, N.Y. TIMES, Apr. 24, 
solution demands a clear understanding of the tools for unwinding the most troubled sovereign bonds. Hence, delineating the current state of the exit consent would make a critical contribution toward greater world economic certainty. In that spirit—and given a lack of scholarly attention to date-this Note systematically examines the history, purpose, and use of the exit consent. It then proposes an interpretation of Assénagon that better accords with the doctrinal assumptions of the bond relationship and the economic realities of the international bond market.

This Note proceeds in five parts. Part I introduces the exit consent's history and mechanics, and Part II presents Katz's rationale for permitting the maneuver, as well as other relevant legal precedents. This background discussion continues in Part III, which details the context and facts of Assénagon. This Part closes with the High Court's rationale for not permitting the exit consent. Part IV elucidates Assénagon's importance with three alternative (though not mutually exclusive) glosses, demonstrating that the High Court's analysis, however well-intentioned, unduly dismisses important market realities in which the exit consent is likely to be used. Part V proposes a means for fitting Assénagon within Katz and its progeny and for moving toward a true transatlantic standard for exit consents. First, it critiques the creation of a lateral good faith duty, finding it inapt for the relationships underpinning a bond like the one at issue in Assénagon. To close, this Part offers a refinement of Assénagon that harmonizes the case with $\mathrm{Katz}$. Although this interpretation includes discarding the lateral good faith duty, more fundamentally, it entails focusing legal analysis upon the underlying bond transaction.

This Note cannot envision the innumerable future scenarios in which an exit consent will be necessary. Rather, it aspires to elucidate the dynamics and doctrines implicated by the exit consent's application. A thorough reexamination of the exit consent's purposes and standards will not only help contain some of the most vexing legal obstacles in finance but also go a long way toward bringing greatly needed steadiness to world markets.

2013, at B1; Richard Silk, Economists See Further Slowdown in China, WALL ST. J. (July 8, 2013, 2:45 AM) http://online.wsj.com/news/articles/SB10001424127887323823004578593200107930868 (attributing sluggish economic growth in China to a paucity of export markets). 


\section{THE HISTORY AND USE OF THE EXIT CONSENT}

Oftentimes, financial innovation gives rise to legal innovation, which, in turn, begets judicial scrutiny. ${ }^{38}$ In a parallel fashion, this Part introduces exit consents, first, by introducing a financial innovation, the junk bond. Second, this Part details how the riskiness of junk bonds gave rise to a legal innovation: the exit consent. This discussion continues in Part II, which catalogues judicial and legislative treatment of the exit consent.

\section{A. History and Context}

The history of the exit consent begins in the 1980s, a decade "mid-wived in a period of dynamic innovation in corporate transactions, ${ }^{, 39}$ perhaps the best-known of which is the junk bond. ${ }^{40}$ Strictly speaking, junk bonds were not innovative; their history extends back to the 1910s, when they financed firms in dire straits. Rather, the use of junk bonds in the 1980s was innovative, as this dusty investment vehicle went from funding companies that had fallen upon hard times to funding new, unproven ventures. ${ }^{42}$ Their emblematic promoter was Michael Milken ${ }^{43}$ a financier who pitched junk bonds using research that showed they outperformed investment-grade securities, even after controlling for default risk. ${ }^{44}$

38. See Roberta Romano, After the Revolution in Corporate Law, 55 J. LEGAL EduC. 342, 348 (2005) ("Modern finance and the new economic theories of the firm provided the analytical tools for understanding the new deals transforming corporate practice in the 1980s and how the legal system should respond to those challenges."); see also Matt Levine, "Everybody's Doing It" Legal Theory Does Not Protect English Bank Restructurings, DEALBREAKER (July 27, 2012, 5:03 PM), http://dealbreaker.com/2012/07/everybodys-doing-it-legal-theory-does-not-protectenglish-bank-restructurings ("When people talk about financial innovation one of the main things they mean is legal innovation.").

39. Romano, supra note 38 , at 342.

40. Id. at 347. Junk bonds are bonds that major credit rating agencies categorize as being below investment grade (that is, with "junk" status). RICHARD A. BREALEY, STEWART C. MYERS \& FRANKLIN ALLEN, PRINCIPLES OF CORPORATE FINANCE 595-96 (11th ed. 2014).

41. See GlenN Yago, Junk Bonds: How High Yield SECurities Restructured CORPORATE AMERICA 14-20 (1991) (discussing the historical background and uses of junk bonds). Such underperforming companies have the evocative name "fallen angels." Id. at 18.

42. Id. at 21 .

43. Id.; see Romano, supra note 38, at 347 ("Milken reinvented junk bonds."). Books about Milken and his investment bank, Drexel Burnham Lambert, make for interesting reading in their own right. See generally, e.g., CONNIE BRUCK, PREDATORS' BALl: THE INSIDE STORY OF DREXEL BURNHAM AND THE RISE OF THE JUNK BOND RAIDERS (1989); JAMES B. STEWART, DEN OF THIEVES (1991).

44. YAGO, supra note 41, at 23. This higher return accounts for the junk bond's more polite appellation: "high-yield bonds." 
As it turned out, the businesses issuing junk bonds were fundamentally riskier than those issuing investment-grade bonds, and therefore default rates for junk bonds were much higher than advertised. $^{45}$

As payment came due on the riskiest junk bonds, their distressed issuers faced difficult choices. A bond evinces a contractual promise to pay. ${ }^{46}$ To avoid breach of contract ${ }^{47}$ and the messy consequences of default, an insolvent bond issuer generally has three options: bankruptcy, bond repurchases, or exchange offers. ${ }^{48}$

First, the bond issuer might choose bankruptcy. ${ }^{49}$ Bankruptcy's main benefit is preventing a "race to the courthouse," a competition among creditors in which each races to sue the debtor to receive priority based upon time of suit. ${ }^{50}$ The insolvent bond issuer benefits from bankruptcy's automatic stay, ${ }^{51}$ which gives the issuer the time to dispose of its obligations and a method for doing so. ${ }^{52}$ Similarly, creditors have a judicially supervised process that ensures their claims are settled upon statutorily sanctioned priority rather than in the order of their lawsuits. ${ }^{53}$ On balance, however, when insolvency arises from a bond obligation, bond issuer and bondholder alike have compelling incentives to avoid bankruptcy. For the bond issuer, bankruptcy's dramatic consequences may make this option an overreaction to defaulting bonds. For the bondholders, though they

45. PATrick A. GAUGHAN, MERgers, ACQuisitions, AND CORPORATE RESTRUCTURINGS 344-45 (5th ed. 2010). Financial literature describes these studies' methodological faults in great detail. To be brief, Milken used research that measured default rates within one or two years after the bonds' issue dates. Later studies - called "mortality rate analyses"- tested default rates ten years after the issue dates and found default rates that debunked the earlier studies. $I d$.

46. 1 RiCHARD A. LORD, WiLLISTON ON CONTRACTS § 2:20, at 175 (4th ed. 1990). A bond issuer makes two kinds of payments to its bondholders: (1) interest, which is paid in regular intervals until the maturity date, and (2) principal or face value, which is paid at maturity. BREALEY ET AL., supra note 40, at 46.

47. See, e.g., 1 Arthur S. Dewing, The Financial Policy OF Corporations 172-74 (6th ed. 1953) (explaining the provisions of bonds and the obligations of the bond issuer and bondholder).

48. BRATTON, supra note 16 , at 411.

49. BREALEY, ET AL., supra note 40, at 850.

50. BRATTON, supra note 16 , at 411.

51. An automatic stay halts almost all actions by creditors so that claims may be satisfied according to legal priority, first priority usually belonging to secured creditors. 11 U.S.C. §362(a) (2012).

52. BRATTON, supra note 16 , at 36 .

53. Id. 
are creditors, ${ }^{54}$ they conceive of themselves as investors who desire predictable streams of passive income. ${ }^{55}$ Hence, the bankruptcy liquidation and priority process ${ }^{56}$ does not comport with bondholders' conceptions of their role.

Further, and especially relevant to a discussion of exit consents, bankruptcy does not exist for a significant class of bond issuers: sovereigns. ${ }^{58}$ To be sure, sovereigns have other incentives for satisfying their creditors, but only up to a point. By way of example, state governments in the United States have political incentives for satisfying their debts, but they are likely to prioritize those debts according to constituency groups. ${ }^{59}$ Given a choice between paying an in-state pensioner or an out-of-state bondholder, state leadership almost always will choose the former. ${ }^{60}$ Realpolitik, therefore, suggests that sovereigns and their creditors must look elsewhere for debt relief.

As a second option, a distressed bond issuer-sovereign or corporate-might consider a bond repurchase, provided via standard clauses in most bonds. ${ }^{61}$ Assuming the debt is publicly traded and the bond issuer has access to cash, the issuer could buy back enough of its bonds to reduce the overall cost of its debt. ${ }^{62}$ Yet therein lies a paradox for the insolvent borrower. If the issuer had the cash to repurchase its bonds, it probably would not need to repurchase its bonds; it simply could continue bond payments. ${ }^{63}$

Because bankruptcy may be impossible or too painful, and because a bond repurchase may be impractical, a bond issuer in need

54. Morey W. McDaniel, Bondholders and Corporate Governance, 41 Bus. LAW. 413, 413 (1986)

55. Cf. BREALEY, ET AL., supra note 40, at 46 (explaining that bondholders regularly receive interest payments from bonds until the bonds' maturity).

56. See id. (describing the bankruptcy liquidation and priority process).

57. See id. at 853 (describing the expectations of a bondholder).

58. Lee C. Buchheit \& G. Mitu Gulati, Exit Consents in Sovereign Bond Exchanges, 48 UCLA L. REV. 59, 67 (2000) ("Unlike [a] [r]epublic . . , a corporate bond issuer always has the option of bankruptcy ....").

59. See Emily D. Johnson \& Ernest A. Young, The Constitutional Law of State Debt, 7 DUKE J. CONST. L. \& PUB. POL'Y 117, 149 (2012) (discussing a state's need to "break or alter promises" to reduce obligations and the negative implications of breaking promises to particular constituencies).

60. Id.

61. BRATTON, supra note 16 , at 342.

62. Id. The financial term for this is the "carrying cost" of liabilities. Id. at 341-42.

63. Id. 
of restructuring is likely to choose the third option: an exchange offer. ${ }^{64}$ In a bond exchange, the bond issuer unwinds its distressed bonds individually by negotiating with its bondholders to accept new bonds with terms friendlier to the issuer. ${ }^{65}$ In turn, the bondholders surrender their right to enforce the contract terms of the old bond. ${ }^{66}$

The terms of the old bond still govern as between the issuer and bondholders who do not participate in an exchange, however, and this presents a significant problem for the distressed issuer. An issuer's prime motivation for an exchange is to lower the total cost of its bond obligations, achieved by lowering its payments across bondholders. If some bondholders do not acquiesce to an exchange and demand some payment above the exchange price, the likelihood increases that other bondholders will refuse the exchange offer. ${ }^{67}$ The result is the "holdout problem," a variant of the classic prisoner's dilemma ${ }^{68}$ in which a rational actor gains more through recalcitrance than acceptance. $^{69}$ The distressed bond issuer seeking a successful exchange needs not only to create an attractive new bond but also to employ some means of making the old bonds unattractive. In practice, it does this by pairing its exchange offer with an exit consent.

\section{B. The Exit Consent}

In the same way that junk bonds were not innovative in themselves, neither was the exit consent (again, strictly speaking) innovative in itself. Rather, the exit consent was an innovative use of provisions already within the bond contract. The operative provision

64. Id.

65. Id.

66. Id.

67. Coffee \& Klein, supra note 14 , at $1228-29$.

68. The prisoner's dilemma is a renowned concept in game theory, explaining how individuals act given asymmetries in information. For a general introduction to the prisoner's dilemma, with explication that is particularly relevant to legal practice, see HowELL E. JaCkson, Louis Kaplow, Steven M. Shavell, W. Kip Viscusi \& David COPE, ANALYTICAL METHODS FOR LAWYERS 41-42 (2d ed. 2010).

69. Coffee \& Klein, supra note 14, at 1228-29. Although the precise economic calculations are well beyond this Note's scope, Professors Coffee and Klein go to lengths to persuasively illustrate that, in an exchange offer without an exit consent, all bondholders earn the most money by not participating in an exchange. Id.; see also Lewis S. Peterson, Note, Who's Being Greedy? A Theoretical and Empirical Examination of Holdouts and Coercion in Debt Tender and Exchange Offers, 103 YALE L.J. 505, 515-24 (1993) (using empirical analysis to demonstrate that "good coercion" remediates the likelihood of holdouts). 
is the modification clause. ${ }^{70}$ Under this provision, the bondholders may modify the contract terms binding the bond issuer, provided that the bondholders pass a resolution that meets some vote threshold, usually a supermajority. ${ }^{71}$ Some clauses require the vote to occur at a physical meeting of bondholders with some specified quorum. ${ }^{72}$ Other clauses permit modifications authorized in writing by a majority of bondholders. ${ }^{73}$ In either drafting, the modification clause likely also includes language specifying that approved bondholder resolutions bind all bondholders. ${ }^{74}$ In crafting an exchange offer, all the issuer need do is to make a new bond that will attract at least as many bondholders as would meet the modification clause's specified vote threshold. $^{75}$ Then, that same group of bondholders would simultaneously cast a vote modifying the old bonds so as to make them unattractive, in hopes of cajoling the participation of would-be

70. For a discussion of the evolution and other uses of modification clauses, also known as collective-action clauses, see generally W. Mark C. Weidemaier \& Mitu Gulati, A People's History of Collective Action Clauses, 54 VA. J. INT'L L. 51 (2013).

71. The relevant language in Anglo Irish's prospectus provided as follows:

The Trust Deed contains provisions for convening meetings of the Noteholders to consider any matter affecting their interests, including the sanctioning by Extraordinary Resolution of a modification of the Notes .... The quorum at any such meeting for passing an Extraordinary Resolution is . . . a clear majority . . . except that at any meeting the business of which includes the modification of certain provisions ... (including modifying the date of maturity of the Notes or any date for payment of interest thereon, reducing or cancelling the amount of principal or the rate of interest payable in respect of the Notes or altering the currency of payment of the Notes ...), ... the quorum shall be one or more persons holding or representing not less than two-thirds in nominal amount of the Notes for the time being outstanding.

Anglo Irish Bank Corp., PLC, Offering Circular, €30,000,000,000 Euro Medium Term Note Programme, If 14(i), at 46 (May 24, 2007), available at http://www.ise.ie/debt_documents/ Anglo\%20Irish\%20Bank\%20Corporation \%20plc_8724.pdf.

72. $I d$.

73. Republic of Ecuador, Offering Memorandum, U.S.\$650,000,000; 9.375\% Bonds Due 2015, at 95 (Dec. 7, 2005), available at http://www.erlassjahr.de/cms/upload/ 21.OfferingMemorandum.pdf ("Any Modification of the indenture or the terms and conditions of the bonds may be made or given pursuant to a written action of the holders of the bonds without the need for a meeting or by vote of the holders of the bonds taken at a meeting of holders ....").

74. See, e.g., Anglo Irish Bank Corp., PLC, supra note 71, at 46 ("An Extraordinary Resolution passed at any meeting of the Noteholders shall be binding on all the Noteholders, whether or not they are present at the meeting....").

75. See, e.g., Landon Thomas, Jr., Hedge Funds Take Another Look at Greek Debt, N.Y. TIMES DEALBOOK (Feb. 22, 2012, 1:47 PM), http://dealbook.nytimes.com/2012/02/22/hedgefunds-take-another-look-at-greek-debt ("Greece-in setting a participation threshold of 66 percent-is more or less indicating that it believes that percentage of investors will participate."). 
holdouts. Alternatively, barring full participation, the vote would alter a covenant, the absence of which would render the holdout investor foolhardy and harmless. ${ }^{76}$

\section{A LEgAl PRIMER ON EXIT CONSENTS}

Like garden-variety contract modifications, changes to bonds are permissible as long as they are consistent with the bonds' contractual language and with mandatory rules supplied by legislatures and courts. $^{77}$ On the one hand, statutory law addresses what changes an issuer may seek (and, perhaps more importantly, what changes an issuer cannot seek); on the other, case law addresses how an issuer may go about seeking those changes. This Part discusses each.

This Part focuses on U.S. precedents for two reasons. First, English courts accept U.S. statutory law as persuasive authority, ${ }^{78}$ and English case law was silent on exit consents until Assénagon. ${ }^{79}$ Second, English law long permitted majority action clauses-the contractual means by which exit consents occur-so most modern legislative and judicial activity guiding the transition from unanimity to majority action clauses has necessarily come from U.S. legislatures and courts. ${ }^{80}$

76. For example, a creative issuer might increase the voting percentage necessary to accelerate the debt, making it nearly impossible for the remaining bondholders to declare an event of default - a course of action that would lower the bond's value without touching a payment term. Andrew Laurance Bab, Debt Tender Offer Techniques and the Problem of Coercion, 91 ColuM. L. REV. 846, 852-53 (1991). In the years since Professor Bab's work, many provisions that an issuer might target have moved to the bond's list of reserved matters, meaning that an issuer typically would require a supermajority vote to be adopted. COMM. ON INT'L ECON. POL'Y AND REFORM, REVISITING SOVEREIGN BANKRUPTCY 3 (2013), available at http://www.brookings.edu/ /media/research/files/reports/2013/10/sovereign \%20bankruptcy/ciep r_2013_revisitingsovereignbankruptcyreport.pdf.

77. 17A AM. JUR. 2D Contracts $§ 507$ (2014) ("[P]arties to an existing contract may, by mutual assent, modify it, provided the modification does not violate the law or public policy, and provided that there is consideration for the new agreement or that it satisfies a statute or is made under circumstances making consideration unnecessary." (footnote omitted)).

78. See Assénagon Asset Mgmt. S.A. v. Irish Bank Resolution Corp., [2012] EWHC (Ch) 2090, [49] (Eng.) (taking note of the Trust Indenture Act, 15 U.S.C. $\$ \S 77$ aaa-bbbb(2012), specifically its "prohibition against the modification of payment terms without the unanimous consent of all the holders of securities issued and registered with the SEC under the US [sic] Securities Act of 1933").

79. Id. at [1] (calling the legality of exit consents a question of first impression under English law).

80. Lee C. Buchheit \& G. Mitu Gulati, Sovereign Bonds and the Collective Will, 51 EMORY L.J. 1317, 1324 (2002). 


\section{A. The Trust Indenture Act of 1939}

Before 1939, some bonds allowed a simple majority of bondholders to modify any provision within the bond. ${ }^{81}$ Still in the shadow of the Wall Street crash of 1929, the then-newly created Securities and Exchange Commission studied majority action clauses and found them detrimental to the interests of all bondholders. ${ }^{82}$ Also present were reports of bondholder majorities acting upon biased or plainly false information. ${ }^{83}$

In response, Congress passed the Trust Indenture Act of 1939 (TIA) $^{84}$ amid the legislative housekeeping that followed the Securities Act of $1933 .^{85}$ As originally adopted, the TIA effectively forbade inclusion of simple-majority action clauses, the provisions that had allowed for prior malfeasance by bond issuers. ${ }^{86}$ Today, the TIA contains two prohibitions relevant to the use of exit consents. Section 316(a) requires that, if the issuer triggers a default event, at least a simple majority of bondholders is required to waive the default. ${ }^{87}$ Section 316(b) prohibits a bond issuer from denying payment to a bondholder without that bondholder's consent. ${ }^{88}$ Together, these sections effectively prohibit an exit consent that would modify a bond's acceleration ${ }^{89}$ or payment ${ }^{90}$ terms.

Congress has said little beyond the TIA on the substance of exit consents, and has said essentially nothing on how distressed issuers

81. BRATTON, supra note 16 , at 347.

82. See SeC. EXCh. COMM'N, Report ON THE STUdy AND InVEstigation OF the Work, Activities, Personnel and Functions of Protective And Reorganization COMMITTEES pt. VIII, at 177-83 (1938).

83. BRATTON, supra note 16 , at 347.

84. Trust Indenture Act of 1939, 15 U.S.C. $\$ \S 77$ aaa-17bbbb (2012).

85. Securities Act of 1933 , ch. 38,48 Stat. 74 (codified as amended at 15 U.S.C. $\$ \$ 77 \mathrm{a}-77 \mathrm{z}$ (2012)).

86. Buchheit \& Gulati, supra note 58 , at $66-67$. Though the TIA is mainly applicable to corporate bonds, sovereign bonds de facto incorporate its strictures because their drafters often used TIA-compliant corporate-bond agreements as templates for sovereign bonds. Id. at 67 .

87. Trust Indenture Act of $1939 \S 316(\mathrm{a}), 15$ U.S.C. $\S 77 \mathrm{ppp}(\mathrm{a})$.

88. Id. § 316(b), 15 U.S.C. $§ 77 p p p(b)$. But see Timothy B. DeSieno \& Robert T. Carey, Changing Terms of Bond Indentures; Are Issuers Overreaching in Consent Solicitations?, N.Y. L.J., Nov. 21, 2005, at 17 (arguing that the "precise meaning" of $\S 316$ (b) is ambiguous).

89. Acceleration terms are within the default clause, which lists the conditions of a default-including a missed principal or interest payment_and a relevant grace period, if any, for rectifying the event of default. See, e.g., Anglo Irish Bank Corp., PLC, supra note 71, III 8-9, at $41-44$.

90. Payment terms include principal amounts, interest rates, currencies of payment, and the like. See, e.g., id. II 14(i), at 46. 
may employ them. That task of definition and interpretation has been left to the courts.

\section{B. Case Law}

English courts traditionally have been silent on exit consents. ${ }^{91}$ In their absence, Delaware and New York, two states well-respected for financial jurisprudence, have provided the leading analysis of the exit consent's propriety.

1. Delaware. Katz v. Oak Industries Inc., the seminal case on exit consents, arose from transactions emblematic of the junk bond era. ${ }^{92}$ Oak Industries Inc. (Oak) had pursued a growth-through-expansion strategy that became troublingly unprofitable by the mid-1980s. ${ }^{93} \mathrm{~A}$ potential lifeline came from Allied-Signal, Inc., a firm that conditioned an offer to buy $\$ 15$ million worth of Oak's stock upon Oak reducing its long-term debt load by 85 percent. ${ }^{94}$ Oak's plan was to settle with existing bondholders using "Payment Certificates," redeemable for cash above the bonds' then-market rate. ${ }^{95}$ The problem was that the bonds included covenants precluding precisely this arrangement. ${ }^{96}$ Oak's solution was to have participating bondholders vote to remove the obstructing covenants and then accept the payment certificates upon abandoning the old bonds. ${ }^{97}$ Though likely to have a positive effect for Oak's shareholders, ${ }^{98}$ this exchange presented bondholders with the apparent Hobson's choice of settling for less than the bonds' face value or being left with bonds that would be less valuable because of the lack of financial protections. ${ }^{99}$ Thereupon, a class of investors sued to enjoin the exchange, claiming that it favored shareholders at the expense of

91. See supra note 79 and accompanying text.

92. In fact, Oak's restructuring process is a part of the curriculum of leading graduate business programs. See generally William A. SAHLMAN \& Burton C. HuRlock, OAK INDUSTRIES, INC. (Harvard Bus. Sch. Case No. 292-086, rev. 1993).

93. Michael C. KNAPP, CONTEMPORARy Auditing: ReAl CASES AND IsSUES 237-38 (7th ed. 2008).

94. Katz v. Oak Indus. Inc., 508 A.2d 873, 876-77 (Del. Ch. 1986).

95. Id. at 876 .

96. Id. at 877 .

97. Id.

98. The company's stock had fallen from $\$ 30$ to $\$ 2$ per share. $I d$. at 875 n.2.

99. See id. at 878 ("[A] rational bondholder [was] 'forced' to tender and consent."). 
bondholders, that its structure was coercive, and that this coercion violated the implied contractual duty of good faith and fair dealing. ${ }^{100}$

The Delaware Court of Chancery disagreed, allowing the exchange to proceed. Before ruling on the facts, the court resolved two threshold matters that would set the framework for analyzing future exit consents. First, the court found that the relationship between a bond issuer and its bondholders had a contractual, not a fiduciary, basis. ${ }^{101}$ Second, it failed to find the use of a "coercive" offer to be determinative on its own. ${ }^{102}$ Instead, the court held that the coercion must be characterized in some negative way, as "wrongfully coercive," for example. ${ }^{103}$ In other words, legal analysis should begin with the adverb modifying "coercive." 104 To supply that normative judgment, the court reasoned that wrongful behavior might be inferred when the coercion violated a contractual duty. ${ }^{105}$ Wrongful behavior is apparent when one party breaches the express terms of a contract; but when, as in Katz, the breached duty was implied rather than expressed, the court supplied the following test:

[I]s it clear from what was expressly agreed upon that the parties who negotiated the express terms of the contract would have agreed to proscribe the act later complained of as a breach of the implied covenant of good faith - had they thought to negotiate with respect to that matter. ${ }^{106}$

Under that test, the facts of Katz suggested no breach. To the contrary, Oak offered shares redeemable above the then-market price, ${ }^{107}$ suggesting a deal the original parties would have approved.

Within a year, the Delaware Court of Chancery applied Katz's test to another case with remarkably similar facts. In Kass v. Eastern Air Lines ${ }^{108}$ the defendant corporation had pursued a merger, also

100. Id.

101. Id. at 879 .

102. Id. at 879-80.

103. Id. at 880 . The court used the homespun example of parents coercing their child to complete her homework by withholding her allowance until it was finished. Although such a situation was clearly coercive, no moral opprobrium could be attached to it. Id.

104. Id.

105. Id.

106. Id.

107. Id.

108. Kass v. E. Air Lines, Inc., Nos. 8700, 8701, 8711, 1986 WL 13008 (Del. Ch. Nov. 14, 1986). 
precluded by covenants within its outstanding bonds. ${ }^{109}$ Again, the issuer had approached its bondholders with an exchange offer including an exit consent, but this time the issuer had added a sweetener: for each bond tendered, the bondholder could receive either cash or a travel voucher. ${ }^{110}$ The court found that the sweetener still fell within the Katz rule because it was offered to all bondholders. ${ }^{111}$ In appraising the overall incentives given to bondholders, Kass instructs courts evaluating exit consents to examine bondholders' economic motivations. ${ }^{112}$ If, for example, a proposed offer creates economic motivations that differ for individual bondholders, it may raise a fairness concern. In this way, Kass suggests a good faith inquiry into the motivations of the bond issuer. Although not legally determinative, then, each party's economic motivations are instructive in answering the threshold question of whether to characterize an exchange as "wrongfully coercive."

Katz's progeny totals more than seventy cases, ${ }^{114}$ some related to exit consents, ${ }^{115}$ others simply construing the good faith duty. ${ }^{116}$ That latter issue of the good faith duty-and the related, broader issue of how far it extends-occupied the attention of other courts, as financial innovation spawned familiar legal questions.

2. New York. New York state courts have also set out important standards relevant to bonds and exit consents. Their rationales are important because New York law governs many bonds, either

109. Id. at 1077 .

110. Id.

111. Id. at 1082 .

112. See id. ("Each will continue to own bonds and thus each has an economic incentive of the same kind to evaluate the question whether any threat to the value of his or her bonds posed by the amendment is more or less valuable than the consideration offered for his or her consent.").

113. Cf. Katz v. Oak Indus. Inc., 508 A.2d 873, 880 (Del. Ch. 1986) (defining the wrongfully coercive test).

114. As of this writing, a Westlaw "KeyCite" search yields seventy-six Delaware cases referring to Katz.

115. E.g., Lonergan v. EPE Holdings, LLC, 5 A.3d 1008 (Del. Ch. 2010); Jedwab v. MGM Grand Hotels, Inc., 509 A.2d 584 (Del. Ch. 1986).

116. E.g., Airborne Health, Inc. v. Squid Soap, LP, 984 A.2d 126, 145-47 (Del. Ch. 2009); In re Kirkwood Kin Corp. v. Dunkin' Donuts, Inc., No. 94C-03-189-WTQ, 1997 WL 529587, at *14-17 (Del. Super. Ct. Jan. 29, 1997). 
through explicit choice-of-law provisions ${ }^{117}$ or as strong persuasive authority. ${ }^{118}$

In New York courts, legal analysis of modern bonds typically begins with Sharon Steel Corp. v. Chase Manhattan Bank, N.A. ${ }^{119}$ Though Sharon's facts were somewhat complicated, ${ }^{120}$ its legal question was direct: How is a court to interpret boilerplate language in one bond when its interpretation will affect other contracts in other market transactions with no real connection to the case aside from sharing the common boilerplate language $?^{121}$ The Second Circuit ruled that boilerplate interpretation is a matter of law, not fact, and that uniformity of interpretation is necessary for encouraging efficient capital markets. ${ }^{122}$

The court in Sharon was clear that a bond's explicit language governs the contract relationship, even if that language is boilerplate ${ }^{123}$ that said, Sharon was generally silent on what implied covenants or parol evidence might inform the bond's interpretation. ${ }^{124}$ Answering this question touched upon the most sensitive legal issue at the heart of "the highest stakes takeover battle ever": ${ }^{125}$ Kohlberg Kravis Roberts's (KKR) leveraged buyout of RJR Nabisco, Inc. ${ }^{126}$ In

117. See, e.g., United Mexican States, Pricing Supplement, U.S. $\$ 30,000,000,000$ Global Medium-Term Notes, Series A, at 12 (Dec. 12, 2002), available at http://data.cbonds.info/ emissions/1378/Prospectus_UMS_2031_tap2.pdf. This prospectus is renowned in the sovereigndebt field because it is the first New York bond issue with a collective-action clause and thus is credited with reviving the practice under New York law in the modern era. Robert B. Ahdieh, Between Mandate and Market: Contract Transition in the Shadow of the International Order, 53 EMORY L.J. 691, 698-702, 708-09 (2004).

118. See Blue Chip Stamps v. Manor Drug Stores, 421 U.S. 723, 762 (1975) (Blackmun, J., dissenting) (characterizing the Second Circuit as the "Mother Court" of securities law).

119. Sharon Steel Corp. v. Chase Manhattan Bank, N.A., 691 F.2d 1039 (2d Cir. 1982).

120. In brief, UV Industries, Inc. (UV), a company that was also party to the lawsuit, had issued bonds with a covenant requiring the company to distribute assets to shareholders upon liquidation. UV sold its assets in piecemeal fashion, seemingly skirting the bond's technical definition of liquidation. Sharon Steel Corp. sought to buy the last piece of UV but was thwarted when certain trustees (including Chase Manhattan Bank) refused to sign over control. Id. at $1042-46$.

121. Id. at 1048 (citing Broad v. Rockwell Int'l Corp., 642 F.2d 929, 942-43 (5th Cir. 1981)).

122. Id. at 1051 .

123. Id.

124. The court did write that corporate custom "might . . create a fact question ...." Id. at 1048 .

125. John Helyar \& Bryan Burrough, Buy-Out Bluff: How Underdog KKR Won RJR Nabisco Without Highest Bid, WALL ST. J., Dec. 2, 1988, at A1.

126. The intrigue and outsized personalities of the takeover made for a best-selling book, Bryan Burrough \& John Helyar, Barbarians at THE Gate: The Fall of RJR 
a leveraged buyout, the buyer satisfies the purchase price of a target company using junk bonds. ${ }^{127}$ Use of junk bonds harms the target company's existing bondholders, however, because their bonds lose value when mixed with the newly acquired low-grade debt. ${ }^{128}$

At the time, an open legal question was whether a target company (as a bond issuer) violated some implied duty owed to its existing bondholders when it undertook actions that necessarily degraded their bonds. ${ }^{129}$ While the question of what duties were owed was hotly contested in the court of public opinion, ${ }^{130}$ the sheer size of the RJR Nabisco leveraged buyout spurred bondholders to bring the question before a court of law. ${ }^{131}$ In Metropolitan Life Insurance Co. $v$. RJR Nabisco, Inc. ${ }^{132}$ two institutional bondholders sued RJR Nabisco and its corporate leadership for breach of the duty of good faith and fair dealing. ${ }^{133}$ Finding that the contract did not expressly prohibit a leveraged buyout, ${ }^{134}$ the court assessed the existence of an implied duty in relation to those express terms. ${ }^{135}$ In other words, an implied duty is not some unlisted covenant but rather an understanding that informs whether each party receives the "fruits of the agreement" provided for in the bond's express terms. ${ }^{136}$ Here, the express terms not only made clear that a leveraged buyout was permissible, ${ }^{137}$ but also that the plaintiff investors had seen and participated in similar

NABISCO (1989), and a made-for-television movie, BARBARIANS AT THE GATE (Home Box Office 1993).

127. BREALEY, ET AL., supra note 40 , at 836.

128. Id. at 838-39.

129. See generally William W. Bratton, Jr., Corporate Debt Relationships: Legal Theory in a Time of Restructuring, 38 DUKE L.J. 92 (1989) (offering various theories of the legal relationships between bond issuers and bondholders).

130. See, e.g., Allan Sloan, The Rape of the Bondholder, FORBES, Jan. 23, 1989, at 67 (arguing that the nature of the bond relationship had changed so as to make bonds more like stocks); Benjamin J. Stein, A New Low? The RJR LBO Makes a Travesty of Fiduciary Responsibility, BARRON's, Nov. 14, 1988, at 16, 17 ("There are questions of a truly mammoth breach of duty to bondholders . . . and not just to bondholders of RJR Nabisco.").

131. See Bratton, supra note 129, at 95 ("Many examples of restructuring-related injury preceded RJR Nabisco, but it took the RJR Nabisco shock to goad players in the bond markets into open combat.").

132. Metro. Life Ins. Co. v. RJR Nabisco, Inc., 716 F. Supp. 1504 (S.D.N.Y. 1989).

133. Id. at 1507 n.6. Other counts included allegations of fraud, violations of securities laws, tortious interference with property and contract, and violation of conveyance laws. Id.

134. Id. at 1516.

135. Id. at 1517.

136. Id.

137. Id. 
transactions. ${ }^{138}$ The court would not "permit an implied covenant to shoehorn into an indenture additional terms [the parties] ... wish had been included." $" 139$

Although New York law is clear on the scope of duties as between bond issuers and bondholders, modern case law is relatively silent on the scope of duties as among the bondholders. The most relevant case is Hackettstown National Bank v. D.G. Yeungling Brewing Co. ${ }^{140}$ in which a member of D.G. Yuengling Brewing Company's (Yuengling) management ${ }^{141}$ — who held both shares and bonds of the company - voted to delay bond payments, which had the effect of strengthening his position as a shareholder. ${ }^{142}$ The bondholders won, ${ }^{143}$ and Hackettstown became the strongest New York authority that stands for the proposition that a majority of bondholders owe some duty to the minority of bondholders. ${ }^{144}$ The complicating factor is that the Yeungling bondholders acted collusively, ${ }^{145}$ which suggests that Hackettstown is about insider control ${ }^{146}$ and raises the question of whether the TIA obviated the underlying controversy. ${ }^{147}$ As for the application of the good faith duty, Hackettstown suggests simply that the vote to modify a bond's terms be conducted in good faith, rather than that there simply exists some independent good faith duty. ${ }^{148}$ This is relevant to current cases because the latter applies to the relationship between the bond issuer and the bondholder, whereas the former seems to be the only judicial basis for inferring a relationship among the bondholders.

138. Id. at 1521 .

139. Id. at 1519.

140. Hackettstown Nat'l Bank v. D.G. Yuengling Brewing Co., 74 F. 110 (2d Cir. 1896).

141. This case also has the interesting wrinkle that Yeungling Brewing Company was a family-run business, so the offending party was a member of the Yeungling family. Id. at 111.

142. Id. at 112 .

143. Id. at 110 .

144. Buchheit \& Gulati, supra note 58 , at 76.

145. Id.

146. Mark J. Roe, The Voting Prohibition in Bond Workouts, 97 YALE L.J. 232, 252 \& n.53 (1987).

147. See 15 U.S.C. $§ 77 p p p(a)$ (2008) (requiring unanimity to amend a bond's payment terms).

148. See Roe, supra note 146, at 252 n.53 ("[In Hackettstown,] insiders attempted to destroy a bond issue but were defeated by a judicial holding that a majority vote to change a bond's terms had to be given in good faith."). 


\section{ASSÉNAGON: THE FALL OF EXIT CONSENTS?}

Assénagon is a remarkable case, and only partly because it marks the first time English law ruled on an exit consent ${ }^{149}$ and one of the few times that the use of an exit consent received judicial disapproval. ${ }^{150}$ The case is also an artifact of modern finance, a window into the collapse of an entire national economy and the curious way in which private debt can morph into sovereign debt. This Part begins by presenting the macroeconomic factors at play, including Ireland's steps toward economic integration with Europe. This context has greater importance because every baby step toward integration presaged the case's thorniest legal and practical implications. This Part then presents the facts of Assénagon, the legal claims arising from the Irish government's use of the exit consent, and the court's rationale for denying use of the exit consent.

\section{A. Background: Ireland, Anglo Irish Bank, and Assénagon Asset Management}

Upon independence from Britain in 1949, Ireland's political leaders pursued economic growth through connectedness. Ireland began a "long love affair" with foreign direct investment in the 1960s, and "embraced free trade" by joining the European Economic Community (the forerunner of the European Union) in $1973 .{ }^{151}$ Economic progress was short-lived: the country's "knuckle-headed policy response" to the oil shocks of the 1970s led the Economist to call Ireland the "poorest of the rich" countries as late as $1988 .{ }^{152}$

Yet fifteen years after being "deemed an economic failure," Ireland had reinvented itself as the "Celtic Tiger."153 Ireland's unemployment and inflation rates were low; its growth records were unparalleled in Europe; and government debt was low. ${ }^{154}$ Reviewing its earlier, harsh assessment, The Economist attributed Ireland's turnaround to monetary consolidation, the creation of a single

149. Assénagon Asset Mgmt. v. Irish Bank Resolution Corp., [2012] EWHC (Ch) 2090, [1] (Eng.).

150. Gelpern, supra note 30.

151. John Peet, The Luck of the Irish, ECONOMIST, Oct. 14, 2004, at 1, 2; see also LAURA Alfaro, Vinati DeV \& STEPHEN MCINTYRe, Foreign Direct InVESTMENT AND IRELAND's TIGER ECONOMY (A) (Harvard Bus. Sch. Case No. 9-706-007, rev. 2010).

152. Peet, supra note 151, at $1-2$.

153. Id.

154. Id. 
European market, a boom in foreign direct investment, and an expansion of the labor force. ${ }^{155}$ Of the country's growing sectors, few were more impressive than real estate. Construction comprised onequarter of Ireland's gross domestic product (GDP), and one-fifth of the workforce built houses. ${ }^{156}$ Fueling the real estate boom was a burgeoning banking sector. At the dawn of 2000, lending to real estate-related concerns comprised 8 percent of composite lending. ${ }^{157}$ By 2007, it had mushroomed to 28 percent. ${ }^{158}$

In an era characterized by explosive growth, Ireland stood out, and among the actors responsible for that growth, Anglo Irish Bank stood far out. Incorporated in 1964 as City of Dublin Bank, the bank acquired Anglo Irish Bank in 1978 and then reconstituted itself under the name of its subsidiary in $1986 .{ }^{159}$ The growth of the new Anglo Irish Bank largely tracked that of the Celtic Tiger. The bank listed three lines of business: treasury services (traditionally commercial paper, currency exchange, and the like); wealth management; and business lending to target customers including "medium size corporat[ions]" and "high net worth individuals in Ireland, the UK and in the greater Boston region in the USA." ${ }^{160}$ As of September 2001, Anglo Irish reported its total assets at around $€ 11$ billion and capital resources of $€ 950$ million. ${ }^{161}$ Barely six years later, in March 2007 , its self-reported total assets were $€ 88$ billion, and capital resources were $€ 7.7$ billion. ${ }^{162}$ The eightfold increase in assets and capital within fewer than six years was astounding and, by most financial measures, unsustainable. ${ }^{163}$

155. Tiger, Tiger Burning Bright, ECONOMIST, Oct. 16, 2004, at 2, 4. Ireland introduced the euro in 1999. Id. at 2.

156. Lewis, supra note 8, at 179.

157. Morgan Kelly, Banking on Very Shaky Foundations, IRISH TIMES, Sept. 7, 2007, at 4.

158. Id.

159. Anglo Irish Bank Corp. PLC, Offering Circular, €1,500,000,000 Euro Medium Term Note Programme, at 41 (Aug. 15, 2001) (on file with the Duke Law Journal).

160. Anglo Irish Bank Corp., PLC, supra note 71, at 51.

161. Anglo Irish Bank Corp., PLC, supra note 159, at 42.

162. Anglo Irish Bank Corp., PLC, supra note 71, at 51.

163. Alan S. Blinder, the economist and former Vice Chairman of the U.S. Federal Reserve, presents a very readable discussion of debt-to-equity ratios, known as leverage ratios, with a particular eye to banking and the recession of the late 2000s. See AlAN S. BLINDER, AFTER THE Music Stopped: THE FinANCE CRIsIS, THE RESPONSE, AND THE WORK AHEAD 50-53 (2013). Truth be told, financial ratios seldom "present very much insight" on their own, but rather are useful in conjunction with other criteria, such as industry standards, historical values, peer companies, and credit ratings. MOORAD CHOUdHRY, THE PRINCIPLES OF BANKING 155-56 (2012). 
To fund its growth, Anglo Irish issued bonds. Among the purchasers was a Munich-based hedge fund, Assénagon Asset Management (Assénagon). Founded in 2007, Assénagon managed $€ 10$ billion, which it claimed to deploy through the use of "experience, independence, profound risk sensitivity and innovative strength." ${ }^{164}$ In September 2009, a German-language fund newsletter compared the credit markets to purchasing lemons, and warned that only ambitious optimism justified some of the prices. ${ }^{165}$ The newsletter's publication date was within the timeframe that Assénagon made some of its most significant purchases of Anglo Irish bonds, by this time priced at 40 percent of their face value. ${ }^{160}$

Assénagon was not alone in identifying a possible real estate bubble. Scholars had warned of overextension as early as $2007 .{ }^{167}$ The same Economist article that assessed Ireland's "economic miracle" summarized the turnaround as "[u]nrepeatable" and the result of "one-off" fortuities. ${ }^{168}$ The article closed by noting Ireland's "dangerous obsession with property."

\section{B. The Case}

In hindsight, it is clear that Ireland exhibited the textbook signs of a real estate bubble. ${ }^{170}$ The year 2008 was unkind to actors across the financial sector ${ }^{171}$ but it was particularly so to Anglo Irish. In September 2008, the bank had $€ 101$ billion in gross assets on its balance sheet, a figure that represented half of Ireland's GDP. ${ }^{172}$ The

164. News Release, Morningstar, Inc., Assenagon Selects Morningstar to Supply European and U.S. Equity Data (Feb. 15, 2011), available at http://corporate.morningstar.com/us/ documents/Quotes/AssenagonSelectsMorningstarEquityData.pdf.

165. Jochen Felsenheimer, Die Goldenen Zitronen, CREDIT NEWSL. (Assénagon Credit Mgmt GmbH, Munich, Ger.), Sept. 3, 2009, at 1, available at http://www.assenagon.com/uploads/ media/Credit_Newsletter_2009_30.pdf.

166. Assénagon Asset Mgmt. S.A. v. Irish Bank Resolution Corp., [2012] EWHC (Ch) 2090, [26] (Eng.). For a discussion of Anglo Irish's collapse in relation to the broader European economic crisis of 2008, see generally Lewis, supra note 8.

167. Kelly, supra note 157.

168. Tiger, Tiger Burning Bright, supra note 155, at 4.

169. Id.

170. Charles P. Kindleberger \& Robert Z. Aliber, MANiAs, PANics, AND Crashes: A History OF FINANCIAL CRISES 274 (6th ed. 2011).

171. See Floyd Norris, A Year of Chaos in Finance, N.Y. TIMES, Dec. 18, 2008, at B1 (calling 2008 "the year the financial system stopped working").

172. Assénagon Asset Mgmt. S.A. v. Irish Bank Resolution Corp., [2012] EWHC (Ch) 2090, [19] (Eng.). Much of a bank's assets are the loans that it extends; hence, the number comes with a good amount of risk. See Emil Lee, Understanding a Bank's Balance Sheet, MOTLEY FOOL 
bank faced a liquidity crisis because of its heavy investment in real estate. ${ }^{173}$ Fearing systemic risk due to Anglo Irish's collapse ${ }^{174}$ the Irish government instituted a number of steps to stem the collapse's effect on the broader economy. ${ }^{175}$ The government began by providing guarantees for the most troubled liabilities, including the bonds eventually purchased by Assénagon, and then by proceeding to nationalize Anglo Irish in January 2009. ${ }^{176}$

The Irish government had spent nearly $€ 23$ billion propping up Anglo Irish before it announced its plan for "appropriate burden sharing" by the bank's bondholders. ${ }^{177}$ The program's aim was for the government to lower its future costs to operate the bank by having Anglo Irish's bondholders agree to lower bond payments, ${ }^{178}$ and the plan was to accomplish reduction of outlays through an exchange offer paired with an exit consent. ${ }^{179}$ The extraordinary resolution presented for a vote was to create an issuer right to redeem the old bonds at 0.001 percent of their face value. ${ }^{180}$ The mechanism to create this right was that the bondholders signed over their proxy votes to IBRC, which IBRC would exercise on their behalf at the physical bondholder meeting. ${ }^{181}$ Assénagon did not accept the offer or attend the bondholder meeting, but more than 92 percent of bondholders agreed. ${ }^{182}$ Because the extraordinary resolutions bound all bondholders whether they voted or not, Anglo Irish exercised its newly created redemption right on November 30, 2010. ${ }^{183}$ For the firm's $€ 17$ million in face value bonds, for which it had paid around $€ 6.8$ million, Assénagon received $€ 170{ }^{184}$

(Jan. 5, 2007), http://www.fool.com/investing/general/2007/01/05/understanding-a-banksbalance-sheet.aspx (acknowledging that "[1]oans represent the majority of a bank's assets" and "come with risk").

173. Assénagon, [2012] EWHC (Ch) 2090, [19].

174. See id. (noting the bank's "systemic importance" to the Irish economy).

175. Id.

176. Id. [19]-[21].

177. Id. [25], [27].

178. Under the burden-sharing program, bondholders were to agree to an 80 percent reduction in bond payments, or roughly 20 percent of the bonds' face value. $I d$. [30]. It was agreed that the reduction equaled what was then the bonds' market value. Id. [36].

179. See id. [29]-[38] (outlining the details of the Irish government's exchange offer).

180. Id. [32].

181. Id. [33].

182. Id. [36].

183. Id. [36]-[37].

184. Id. [37]. 
Perhaps unsurprisingly, Assénagon sued, challenging the validity of the exchange itself in the Chancery Division of the High Court of Justice of England and Wales. Assénagon advanced three separate claims: First, the resolution conferred an unlawful power of expropriation to the Irish government. ${ }^{185}$ Second, the bank, not the bondholders, held the notes at the time of the vote, which technically violated the bond's disenfranchisement provision. ${ }^{186}$ Third, the resolution was an abuse of power by the majority of bondholders against the minority. ${ }^{187}$

For claim one, Assénagon's theory was that the exchange offer constituted expropriation because the payout was so significantly reduced relative to the bonds' face value. ${ }^{188}$ The expropriation claim carried two questions: a question of outcomes and a separate question of processes. On the outcomes question, though courts are generally reluctant to appraise economic values,${ }^{189}$ the court seemed willing to side with Assénagon that the nominal amount of the payout was equivalent to expropriation. ${ }^{190}$ The dispositive question, instead, was one of processes. In other words, the right of redemption created by a vote of the bondholders was what enabled the nominal amount of the payout. ${ }^{191}$ For that reason, the payout, albeit jaw-droppingly low, was not grounds for judicial scrutiny; rather, it was the process that provided for the government to effect the low payout that should have been legally determinative. ${ }^{192}$ Hence, on this claim, the court found in favor of Anglo Irish. ${ }^{193}$

The next two claims, however, proved problematic for the bank. For claim two, Assénagon's argument was that the process of proxy voting violated the bond's disenfranchisement provision. ${ }^{194}$ Anglo Irish's notes prohibited the bank from "vot[ing] at any meeting in

185. Id. [39].

186. Id.

187. Id.

188. Id.

189. See RESTATEMENT (SECOND) OF CONTRACTS $§ 79$ (1981) ("If the requirement of consideration is met, there is no additional requirement of . . . equivalence in the values exchanged....").

190. Assénagon, [2012] EWHC (Ch) 2090, [54] (noting that the plaintiff made a "powerful submission" when arguing that an English statute would not permit so low of a payout).

191. Id.

192. Id. [52].

193. Id. [87].

194. Id. [57]. 
respect of Notes beneficially held by it or for its account." ${ }^{195}$ Generally speaking, the purpose of such provisions is to constrain the possibility of vote manipulation and to promote fair dealing. ${ }^{196}$ The court seized upon the phrase "at any meeting." Under the court's reasoning, when the bondholders committed their proxy votes in favor of the extraordinary resolution, they were voting before the meeting. ${ }^{197}$ Hence, the bank held the notes at the meeting, thus violating the literal application of the contract's language. ${ }^{198}$

In the court's opinion, claim two-the disenfranchisement claim-was sufficient to decide the case for Assénagon. ${ }^{199}$ But, because of claim three's "wide importance [to] the bond market"200 (the alleged abuse of power by the majority of bondholders against the minority), the court went on to discuss this claim. As a threshold matter, the court emphasized that majorities are given the power to bind minorities only for the benefit of the entire class of investors. ${ }^{201}$ Over time, this principle was extended from partners in an enterprise to shareholders, ${ }^{202}$ and later from shareholders to bondholders. ${ }^{203}$ In all contexts, though, the power to bind minorities comes from the company itself, reinforcing why that power must be directed in good faith for the benefit of the company's interest holders. ${ }^{204}$

Then, importantly, the court applied the bondholder's majority power to bind minorities laterally, finding that a contract governing a relationship between borrower and lender also establishes duties among the lenders themselves. ${ }^{205}$ When the court applied these principles to the facts of Assénagon, it deemed impossible the conclusion that the exchange package was directed for the benefit of the entire class of bondholders. ${ }^{206}$ The "correct [legal] question," then,

195. Id. [16].

196. E.g., Michael Bradley \& G. Mitu Gulati, Collective Action Clauses for the Eurozone: An Empirical Analysis 38-39 (Mar. 28, 2013) (unpublished manuscript), available at http://papers.ssrn.com/sol3/papers.cfm?abstract_id=1948534.

197. Assénagon, [2012] EWHC (Ch) 2090, [19].

198. Id.

199. Id. [69].

200. $I d$.

201. Id. [41].

202. Id. [42].

203. Id. [43].

204. Id. [44].

205. Id. [45] (citing Redwood Masterfund Ltd. v. TD Bank Europe Ltd., [2002] EWHC (Ch)

2703, [91]-[92], [2006] 1 B.C.L.C. 149, 175 (Eng.)).

206. Id. [71]. 
was whether a majority should be able to "lend its aid" to expropriation. ${ }^{207}$ The court found that the majority did precisely this, a conclusion at variance with the justifications by which majorities are able to bind minorities and, therefore, a breach of the good faith duty among creditors. ${ }^{208}$ "[O]ppression of a minority is of the essence of exit consents of this kind, and it is precisely that at which the principles restraining the abusive exercise of powers to bind minorities are aimed." ${ }^{209}$ Hence, the court deemed the Irish government's use of the exit consent in the burden-sharing program to be unlawful. ${ }^{210}$

\section{GLOSSES ON ASSÉNAGON}

So is Assénagon simply a new wrinkle in the law of exit consents, or does it signal the beginning of their end in the international bond markets? Although many immediate reactions to the case suggested that it is the latter ${ }^{211}$ this Note argues that Assénagon is more properly the former. As one writer put it, when describing the duties in another financial relationship, judicial opinions are akin to data points, each one shaping the direction market participants take. ${ }^{212}$ With Assénagon, the problem for the legal observer-whether an academic, a practitioner, a bond issuer, or a bond investor-is that the case could represent one of several data points, each suggesting different directions. This Part aggregates those data points by offering three different, but hardly mutually exclusive, interpretations of Assénagon. The analysis proceeds to Part V, which proposes a single

$$
\begin{aligned}
& \text { 207. Id. [84]. } \\
& \text { 208. Id. [85]. } \\
& \text { 209. Id. [86]. } \\
& \text { 210. Id. [87]. }
\end{aligned}
$$

211. See, e.g., Joseph Cotterill, More on Those Endangered Exit Consents, FT ALPHAVILLE (July 31, 2012, 7:38 P.M.), http://ftalphaville.ft.com/2012/07/31/1102671/more-on-thoseendangered-exit-consents (“Mr. Justice Briggs didn't merely take a technical potshot at exit consents. He laid a depth charge ...."); Gelpern, supra note 30 (noting that "this decision takes away a major source of flexibility" and "is a really big deal"); Levine, supra note 38 ("U.S. courts have allowed [the exit consent] for 25 years, so it's become standard. ... Until today.").

212. Emily D. Johnson, Note, The Fiduciary Duty in Mutual Fund Excessive Fee Cases: Ripe for Reexamination, 59 DUKE L.J. 145, 173 (2009); see also Developments in English Law: Chancery Division of High Court Overturns Exit Consent, SiMPSON THACHER 1 (Aug. 3, 2012), http://www.stblaw.com/google_file.cfm?TrackedFile=4B46116603DBECD896B179\&TrackedFo lder=585C1D235281AED9B6A07D5F9F9478AB5A90188899 (arguing that the ruling "calls into question the continued efficacy of established restructuring techniques that have used exit consents as a core mechanic and introduces significant uncertainty into the English law governed bond market"). 
direction forward by arguing for a transatlantic standard for exit consents that combines the most sensible features of each interpretation.

\section{A. First Gloss: Assénagon Stands for Careful Contracting}

Bonds are contracts, and judicial contract analysis begins with a contract's express terms. ${ }^{213}$ When one party's conduct violates those express terms, a breach of contract exists, against which the nonbreaching party may make a claim and succeed in court. ${ }^{214}$ In Assénagon, the structure of the exit consent vote by proxy violated the contract's express term that such votes be conducted "at [a physical] meeting." ${ }^{215}$ That breach was sufficient to decide the case, ${ }^{216}$ and, hence, for the issuer contemplating an exit consent, Assénagon stands for carefully aligning the exit consent's process with the letter of the contract, or, if possible, drafting the contract to provide for the process by which the issuer envisions obtaining an exit consent.

The simple appeal of this interpretation is that it also borders on being a truism: bonds are contracts, and contracts mean what they say. Moreover, some features of the bond market render this interpretation especially insightful. The first feature is the character of the parties. In the bond context, they are almost always sophisticated ${ }^{217}$ which carries the presumption that they understand the processes that follow a default in payment or precede a possible default. ${ }^{218}$ Accordingly, bond issuers should use care in the provisions they select, knowing bondholders will be aware of differences in language.

Complementing this first feature-namely, that sophisticated parties have the ability to craft bond contracts as they wish-is the second feature, which is that they actually $d o$ craft bond contracts

213. See, e.g., Assénagon, [2012] EWHC (Ch) 2090, [56]-[68] (discussing the manner in which IBRC's actions conflicted with the language of its indentures).

214. See Restatement (SeCOND) OF CONTRACTS § 1 (1981) (defining a contract as "a promise or a set of promises for the breach of which the law gives a remedy, or the performance of which the law in some way recognizes as a duty").

215. Assénagon, [2012] EWHC (Ch) 2090, [62].

216. See id. [69] ("My conclusions [on the breach of express terms] are sufficient to determine this case in favour of the claimant.").

217. See id. [10] (claiming that the parties in the Anglo Irish case were, for the most part, "at the time of the exchange offer, sophisticated professional investors").

218. See Metro. Life Ins. Co. v. RJR Nabisco, Inc., 716 F. Supp. 1504, 1509 (S.D.N.Y. 1989) (deeming sophisticated investors well aware of contract terms, as they likely "review [the terms] carefully before lending hundreds of millions of dollars to any company"). 
carefully. The literature on modification, or collective-action, clauses is vast, revealing a complex history and a multitude of variations across the provisions' several discrete aspects. Modern practice exhibits this variation specifically on the meeting requirements. Some bonds explicitly require a meeting to modify the agreement $;{ }^{219}$ for others, a written resolution suffices. ${ }^{220}$ In Assénagon, the attention given to the phrase "at any meeting" may come across as formalistic, ${ }^{221}$ but other recent, high-profile bond litigation shows that courts on both sides of the Atlantic use this literalist approach. ${ }^{222}$

Although the preceding analysis establishes two doctrinal justifications for accepting the "at any meeting" language at face value, market practice supplies a separate reason for a meeting requirement. Often, distressed bonds are for significant sums of money-each issue may be worth well more than half a billion dollars-which require a group of banks with broad customer bases to raise all of the funds. ${ }^{223}$ The influence of the institutional investor does mean that bondholders have a reasonable idea of the identity of the other bondholders. ${ }^{224}$ Still, though bondholder identities may be ascertainable, they are not static; publicly traded bonds may change hands several times beyond the point of the initial offering. ${ }^{225} \mathrm{~A}$ meeting requirement gives a forum to cut through the uncertain identities so that the bondholders or their representatives may physically identify each other.

Of course, careful contracting only works as an explanation to the extent that the parties have a mutual understanding of the same language. ${ }^{226}$ The problem, as specifically applied to Assénagon's facts, is that it is unclear whether the investors would have known the disenfranchisement provision was a part of the deal. Although the

219. See Anglo Irish Bank Corp., PLC, supra note 71, II 14(i), at 46 (describing a meeting in the modification clause).

220. See Republic of Ecuador, supra note 73, at 95 (allowing for a written resolution).

221. Assénagon, [2012] EWHC (Ch) 2090, [62].

222. See NML Capital, Ltd. v. Republic of Arg., 699 F.3d 246, 258-59 (2d Cir. 2012) (applying a literal reading to the phrase "pari passu" within sovereign bond contracts).

223. BREALEY, ET AL., supra note 40, at 625-26.

224. See Kahan, supra note 18, at 1060 ("The market for corporate bonds is heavily dominated by institutional investors.").

225. Steven L. Schwarcz \& Gregory M. Sergi, Bond Defaults and the Dilemma of the Indenture Trustee, 59 ALA. L. REV. 1037, 1038 (2008).

226. See RESTATEMENT (SECOND) OF CONTRACTS § 5(1) (1981) ("A term of a promise or agreement is that portion of the intention or assent manifested which relates to a particular matter.”). 
contract language of a bond that actually binds the parties is the indenture, the language of the indenture is supposed to correspond to the prospectus, the carefully crafted legal document that describes the legal features. Here, the prospectus for the notes that were exchanged does not correspond with the language the court cites. In U.S. securities practice, the omission might warrant action by the Securities and Exchange Commission for material deviation between the offering document and the actual contract. ${ }^{227}$ This fact, rather, stands for the broader principle that careful contract construction only goes as far as the expectations that the contracting parties share based upon the common language.

\section{B. Second Gloss: Assénagon Merely Creates TIA-Like Protections}

After discussing "bespoke" contract provisions-those agreed upon specifically by the parties-the High Court went on to discuss provisions read into contracts by force of statute. ${ }^{228}$ As an example, the High Court mentioned the operation of the TIA under U.S. law. ${ }^{229}$ A U.S. court likely would not have reached the good faith issue when the modification of the redemption amount in this manner would seem to violate TIA Section 316(b) ${ }^{230}$ Under this gloss, the High Court's use of the TIA is purposive, and Assénagon, therefore, simply creates something like the TIA for bonds governed by English law.

This gloss, too, has the appeal of being intuitively accurate, but it overlooks the distinction between the contractual term being changed and the process by which it is changed. The redemption amount is not legally determinative under Assénagon or Katz. Rather, the TIA says only that one needs a unanimous vote to change a payment term, which Assénagon seems to imply in its discussion of minority oppression. ${ }^{231}$ The literal reading of the TIA is that it puts payment terms off-limits for modification, but a more purposive readingwhich is in line with what the Assénagon court found-is that the TIA says no process that results in a change to a payment term is valid

227. Query whether an investor would actually sue because the disenfranchisement provision makes the bond stronger from his perspective.

228. See Assénagon Asset Mgmt. S.A. v. Irish Bank Resolution Corp., [2012] EWHC (Ch) 2090, [48]-[49] (Eng.).

229. Id. [49].

230. Cf. Trust Indenture Act of 1939 § 316(a), 15 U.S.C. $§ 77 p p p(a)$ (2012) (forbidding changes to payment terms without unanimous consent of bondholders).

231. See Assénagon, [2012] EWHC (Ch) 2090, [53]-[54] (discussing the value of preserving the minority of bondholders against the majority taking its remuneration). 
unless it has unanimous consent. ${ }^{232}$ This reading of the TIA finds more support in the opinion's discussion of intercreditor duties.

\section{Third Gloss: Assénagon Creates a Lateral Good Faith Duty}

In the context of an exit consent, a breach of the good faith duty exists when the issuer constructs an exchange offer that is wrongfully coercive. ${ }^{233}$ To this principle, Assénagon adds that a breach of the good faith duty also exists when a majority of the bondholders participate in the vote that creates the wrongfully coercive situation. ${ }^{234}$ Or does it? Assénagon's discussion of the lateral good faith duty is when the language is at its most forceful. Yet it also comes with the proviso that the preceding discussion on disenfranchisement was enough to decide the case. ${ }^{235}$ This suggests that what follows (that is, the discussion of the lateral good faith duty) is dicta-strong and ringing language to be sure, but of no legal consequence.

Of course, the observer cannot look away from the import of this language on the lateral good faith duty for two reasons. First, the court couches its discussion in the alternative, offering its rationales in anticipation that an appeals court might overturn its application of the contract's language. ${ }^{236}$ Second, and perhaps more importantly, the case reaches fundamental questions of contract law, questions of parties involved, default and mandatory rules, and implied duties. ${ }^{237}$ Even if this is not the correct interpretation of Assénagon, because of the questions it raises and the interest it has received, it merits attention. Whether the standards this interpretation implies are the correct standards, however, spawns another discussion altogether.

\section{THE RISE OF THE EXIT CONSENT: TOWARD A TRANSATLANTIC STANDARD}

Debt markets demand certainty. Among the most salient criticisms of using junk bonds to fund leveraged buyouts was that

232. See Trust Indenture Act $\S 316(\mathrm{a})$.

233. Katz v. Oak Indus. Inc., 508 A.2d 837, 879-80 (Del. Ch. 1986).

234. Assénagon, [2012] EWHC (Ch) 2090, [84]-[85] (establishing that the exit consent depends upon action by a majority of bondholders and that it is no defense to say it is done at the issuer's invitation).

235. Id. [69].

236. See id. (addressing the issue on the hypothesis that the disenfranchisement claim does not apply).

237. See id. (reaching the issue also because of its broad importance to the bond market). 
such use turned the bond into a fundamentally different investment vehicle. ${ }^{238}$ Further, assurances of certainty are especially necessary in the context of sovereign debt, as the international character of the parties already injects an unhelpful element of instability. ${ }^{239}$ In an environment in which global finances are in flux, legal principles ought to provide assurance to world markets.

For markets in search of certainty, Assénagon was a "depth charge" against the exit consent. ${ }^{240}$ Far from a "technical potshot," the case goes to the foundation of the relationships inherent in contracts generally and transnational bonds specifically. ${ }^{241}$ It is this relational focus-and its position as precedent given IBRC's dropped appealthat has stirred academics and practitioners to attention. ${ }^{242}$ But, both the court and its observers should save their concern for another case.

Assénagon is an example of difficult facts making for bad law, but it need not be this way. Especially given the tumult in modern sovereign-debt markets, it is imperative that bond issuances on either side of the Atlantic have recognizable and familiar standards for workouts. Bankruptcy is not an option for the sovereign debtors who are most likely to use the exit consent. ${ }^{243}$ Even if the facts of each default or near-default vary, parties on both sides of the bond transaction should have consistent, clear expectations regarding the manner in which their dispute will be settled.

\section{A. The Rule of Katz Covers the Facts in Assénagon}

A natural rejoinder to the plea for consistency and familiarity is that, if those two criteria are paramount, then all New York law need do is adopt Assénagon's standards as they apply to exit consents. Yet the problem with Assénagon is that it does not meaningfully add to $\mathrm{Katz}$, which embodied the expectations most parties had for the process of exit consents. Similar expectations are apparent in a case

238. See Sloan, supra note 130 (arguing that use of bonds for leveraged buyouts effectively converted the bonds into stocks).

239. See Odette Lineau, Who Is the "Sovereign" in Sovereign Debt?: Reinterpreting a Rule of Law Framework from the Early Twentieth Century, 33 YALE J. INT'L L. 63, 66 (2008) (providing that "a purely statist approach to sovereignty," which "assumes the continuity of sovereign obligations across successive regimes and therefore mandates the payment of all debt," is vital to "the stability and certainty required for cross-border lending").

240. Cotterill, supra note 211.

241. Id.

242. E.g., Gelpern, supra note 30.

243. See supra notes $49-60$ and accompanying text. 
that the Assénagon court approvingly cited, Azevedo v. Imcopa Importação. ${ }^{244}$ There, a Brazilian soybean producer sought to restructure its debt and offered "consent payments" to bondholders voting in favor of the change. ${ }^{245}$ The Azevedo court found no impropriety, ${ }^{246}$ and, to buttress its finding, it discussed the Kass decision. ${ }^{247}$ The careful observer can draw a few implications from this fact. For one, the Assénagon court's disapproval of $\mathrm{Katz}$ is at least somewhat mitigated when, elsewhere, the same court, albeit a different subdivision of that court, approves of another decision for which Katz was a necessary antecedent. More fundamentally, the inclusion of Azevedo suggests that, just as Katz and Kass have been read together, so too can Azevedo and Assénagon be understood as twin (and similarly alliterative) pillars of English jurisprudence on exit consents. In this way, viewed as a continuation of an earlier case, Assénagon does not mark the exit consent's death knell, but rather its outer limit.

Perhaps the greatest irony of Assénagon is that, although the court wrote that it refused to apply $\mathrm{Katz}$, its reasoning effectively extended $\mathrm{Katz}$. In $\mathrm{Katz}$, the ultimate test is whether a court can deem an exchange to be wrongfully coercive, which a court appraises by ascertaining whether the contract's original parties would have forbidden the exchange had they possessed the foresight to imagine it. ${ }^{248}$ In U.S. practice, the question is moot because the TIA prohibits such modifications to core payment terms without the unanimous consent of bondholders. ${ }^{249}$ The unanimity requirement here presumes that the modification is being undertaken for the benefit of the entire class of bondholders.

Even assuming a contract regime in which unanimity is not required for lowering a payment term, it is difficult to envision a scenario in which lowering the payment ratio to 0.001 percent of face value would not be deemed wrongfully coercive. Simply put, Assénagon could fit easily with Kass among the progeny of Katz. As a corollary, Assénagon could stand as an extension of Katz, illustrating

\footnotetext{
244. Azevedo v. Imcopa Importação, [2012] EWHC 1849 (Comm.).

245. Id. [2]-[13].

246. Id. [61].

247. Id. [55]-[59]; see infra Part II.B.1.

248. See supra Part II.B.1.

249. See Buchheit \& Gulati, supra note 80, at 1335 (explaining that, in the United States, changes to the payment terms of sovereign bonds cannot be made without the unanimous consent of the bondholders).
} 
the durability of the good faith rule. It need not stand alone as a refutation of $\mathrm{Katz}$, especially given the consequences for the broader sovereign debt markets.

\section{B. The Lateral Good Faith Duty Is Inapt in Modern Debt Markets}

The creation of a lateral good faith duty to avoid wrongful coercion extends $\mathrm{Katz}$ in an unnecessary way. More generally, it confounds the expectations of parties to a bond agreement. Although bonds are contracts, the modern understanding of many of their default and mandatory rules comes from securities practice. ${ }^{250}$ This is different from a loan; indeed, borrowers often choose bond financing because they want to avoid a bank loan. ${ }^{251}$ The bonds in Assénagon would have a "presumption" of being securities, and upon further review, evince the characteristics that suggest a longer-term relationship than a loan. ${ }^{252}$ The securities precedent here is persuasive rather than determinative because it applies only to U.S. law; however, it does demonstrate the expectations that professionals in this field bring to different investments. Hence, the foundational understandings of securities are illustrative of the expectations that bondholders have when entering into the agreements.

In issuer transactions, the focus of U.S. law is upon the distribution of the securities themselves, and thus focuses on the transaction. ${ }^{253}$ Claims in this sphere, therefore, follow along the distribution channels from purchasers up to issuers, ${ }^{254}$ and, although the transactional focus does not establish contractual duties, that focus is at least persuasive evidence of the way in which securities purchasers view the relationship.

Assénagon turns that relationship on its side and would have securities purchasers looking to other purchasers for claims. In some instances-when a conflict of interest arises or the underlying investment vehicle is different-there is justification for the lateral

250. See, e.g., Reves v. Ernst \& Young, 494 U.S. 56, 67 (1990) (classifying securities under the "family resemblance" test).

251. See supra Part I.A.

252. Compare Reves, 494 U.S. at 67-69 (describing securities as being long-term due to their "fundamental essence" as an investment), with Assénagon Asset Mgmt. S.A. v. Irish Bank Resolution Corp., [2012] EWHC (Ch) 2090, [9] (Eng.) (listing the bond's due date as giving a long-term maturity).

253. James D. Cox, Robert W. Hillman \& Donald C. LANGEVoort, Securities REGUlATION: CASES AND MATERIALs 1-2 (6th ed. 2009).

254. Id. 
approach, but Assénagon's facts do not align with these exceptions. Under New York law, Hackettstown comes closest to finding a relationship among creditors that would imply a good faith duty. ${ }^{255}$ Yet that case's utility is limited as to Assénagon specifically because Hackettstown does not establish a lateral good faith duty, but rather deals with the conflict of interest that exists when a creditor is also a principal shareholder. ${ }^{256}$ As scholars Lee Buchheit and Mitu Gulati point out, TIA $\S 316$ (a) obviates this concern when it prohibits an obligor or someone controlled by the obligor from changing the terms of the bond. ${ }^{257}$ So too did Anglo Irish's debentures do away with this concern when they disenfranchised the issuer from voting on bonds held for its own account. ${ }^{258}$ With Hackettstown as precedent, the lateral good faith duty is a solution to a problem that no longer exists. Of modern precedents that Assénagon cites, Redwood Masterfund, Ltd. v. TD Bank Europe Ltd. ${ }^{259}$ is most on point-but it too has limited utility. In Redwood, a project-finance case, the underlying transaction differed in fundamental ways from that of the transaction in Assénagon. ${ }^{260}$ So, though illustrative and perhaps persuasive, a project-finance precedent should not be controlling in an international debt-finance case. ${ }^{261}$

The modern bond market gives little foundation for creating a lateral good faith duty. One reason supporting a modification clause's meeting requirement is that there is an active secondary market for publicly traded bonds, so the individual bondholders are constantly in

255. See supra Part II.B.2.

256. Hackettstown Nat'l Bank v. D.G. Yuengling Brewing Co., 74 F. 110, 112 (2d Cir. 1896).

257. Buchheit \& Gulati, supra note 58, at 76.

258. Assénagon Asset Mgmt. S.A. v. Irish Bank Resolution Corp., [2012] EWHC (Ch) 2090, [16] (Eng.).

259. Redwood Masterfund, Ltd. v. TD Bank Eur. Ltd., [2002] EWHC (Ch) 2703, [2006] 1 B.C.L.C. 149.

260. In Redwood, the underlying transaction was a syndicated loan agreement, id. [1]-[3], [2006] 1 B.C.L.C. at 151-52, whereas in Assénagon, the underlying transaction was one of bondholder note exchanges, Assénagon [2012] EWHC 2090 [1].

261. The specifics of project finance are well beyond the scope of this Note. It should suffice to say that, in project finance, there is a very specific funding object—such as building a bridge or a power plant, or excavating a mine-and lenders receive payout from the project itself. Therefore, the lenders draft contracts very specifically to maintain constant communication as between themselves and the borrower, and among themselves to coordinate when sums of money will be necessary and how the project is progressing. Hence, the implied duty of good faith probably owes as much to these considerations as to any black-letter doctrine. See GRAHAM D. VinTER, PROJECT FINANCE: A LEGAL Guide xix (3d ed. 2006) (outlining private sponsor objectives in entering a project and the intricacies within each objective that would clearly necessitate careful contracting and constant communication and trust between parties). 
flux. ${ }^{262}$ It is difficult to impose duties between the bondholders when that class is changing. Similarly, even the identities of the parties may change. ${ }^{263}$ Assénagon, for example, is now known as XAIA Investment. ${ }^{264}$ The only anchor in these contractual relationships is the identity of the issuer. This is who bondholders receive information from, and this is who constructs the exchange offer to begin with. ${ }^{265}$ This relationship between bond issuer and bondholder girds the bond from the beginning. Hence, it is this relationship-and this relationship alone-that should supply duties inherent in the bond.

However incorrectly applied the lateral standard may be, it is at least well-intentioned. The proper construction of the exit consent standard would keep those intentions but apply them along the understood lines of contract duties. Going forward, bond issuers considering an exchange can probably avoid legal scrutiny when their actions are consistent with the contract's language. They can probably further insulate themselves when their offers are beyond reproach under the standards of Katz. Beyond that, any conceptions of duties owed by the bondholders may be instructive, but they should not be legally determinative.

\section{CONCLUSION}

Amid the economic tumult of the late aughts, scholars Carmen Reinhart and Kenneth Rogoff proposed the this-time-is-different theory of financial markets. ${ }^{266}$ The theory's name was tongue-incheek, as its gist was that financial turmoil occurs when market actors hubristically assume that "financial crises are things that happen to other people in other countries at other times.... We [the modern market actors] are doing things better, ... we have learned from our past mistakes." ${ }^{267}$ This Note argues that the same words of caution apply to the legal innovations tailored to that tumult. True innovation

262. See Schwarcz \& Sergi, supra note 225, at 1037-38 (explaining that the collective-action issue that often occurs with publicly traded bonds is due to bondholders' inability to act "as a cohesive group" when comparably small investments "minimiz[e] [the] economic incentive to take action or cooperate").

263. Id. at 1038 .

264. Bradley, supra note 29.

265. See Schwarcz \& Sergi, supra note 225, at 1039 (describing the issuer and indenture language as being the binding force of a bond through indenture trustees).

266. REINHART \& ROGOFF, supra note 36 , at 1.

267. Id. 
is rare and traditional doctrines are as apt for modern economic shocks as they were for their antecedents. As it relates to the exit consent, the rule of $\mathrm{Katz}$ resolves the good faith duty in a manner that is practical, familiar, and satisfying. Further, creating a transatlantic standard on exit consents by repudiating Katz will not resolve Anglo Irish's legal problems, which are ongoing ${ }^{268}$ and continue to stir controversy.

Though Ireland's economic recovery may be in sight, ${ }^{270}$ the resolution of future, unforeseen economic crises will rest upon interpretation of this remarkable case, Assénagon. Against a background of market paradigms influx, courts should adapt rather than upend the implicated legal paradigms. Buttressing fundamental legal principles would do much in the way of bolstering a stronger, steadier macroeconomy.

268. Mary Carolan, Anglo Irish Bank Criminal Cases Could Run for Several Years, High Court Told, IRISH TIMES (Jan. 14, 2014, 6:36 AM), http://www.irishtimes.com/business/sectors/ financial-services/anglo-irish-bank-criminal-cases-could-run-for-several-years-high-court-told1.1653989.

269. E.g., Floyd Norris, In Ireland, Dire Echoes of a Bailout Gone Awry, N.Y. TIMES, Jul. 4, 2013, at B1.

270. Eamon Quinn, Irish Central Bank Sees Start of Recovery; Bank of Ireland Says Too Early To Say Crisis Is Over, WALL ST. J. (Jan. 29, 2014, 7:00 AM), http://online.wsj.com/news/ articles/SB10001424052702304428004579350252187548142. 